\title{
Williamsia marianensis sp. nov., a novel actinomycete isolated from the Mariana Trench
}

Correspondence

Michael Goodfellow

m.goodfellow@ncl.ac.uk

\author{
Wasu Pathom-aree, ${ }^{1} \dagger$ Yuichi Nogi, ${ }^{2}$ lain C. Sutcliffe, ${ }^{3}$ Alan C. Ward, ${ }^{1}$ \\ Koki Horikoshi, ${ }^{2}$ Alan T. Bull ${ }^{4}$ and Michael Goodfellow ${ }^{1}$ \\ 'Division of Biology, King George VI Building, University of Newcastle, Newcastle upon Tyne \\ NE1 7RU, UK \\ ${ }^{2}$ Extremobiosphere Research Center, Japan Agency for Marine-Earth Science and Technology \\ (JAMSTEC), 2-15 Natsushima-cho, Yokosuka 237-0061, Japan
}

${ }^{3}$ School of Applied Sciences, Northumbria University, Newcastle upon Tyne NE1 8ST, UK

${ }^{4}$ Department of Biosciences, University of Kent, Canterbury, Kent CT2 7NJ, UK
The monospecific genus Williamsia was proposed by Kämpfer et al. (1999) to accommodate an unusual mycolicacid-containing actinomycete. The taxon currently contains three recognized species, Williamsia muralis Kämpfer et al. 1999, Williamsia maris Stach et al. 2004 and Williamsia deligens Yassin and Hupfer 2006, species that encompass strains isolated from indoor building materials, deep-sea sediment and human blood, respectively. These species form a distinct $16 \mathrm{~S}$ rRNA clade within the evolutionary radiation occupied by mycolic-acid-containing actinomycetes, i.e. by organisms classified in the suborder Corynebacterineae Stackebrandt et al. 1997 (Butler et al., 2005; Soddell et al., 2006).

The present investigation was designed to determine the taxonomic status of an actinobacterial strain, isolate $\mathrm{MT} 8^{\mathrm{T}}$, that had been isolated from a deep-sea sediment and was considered to represent a member of the genus Williamsia (Pathom-aree et al., 2006). The isolate was the subject of a polyphasic taxonomic study, which showed that it merited recognition within a novel species of the genus Williamsia.

tPresent address: Department of Biology, Faculty of Science, Chiang Mai University, Chiang Mai 50200, Thailand.

The GenBank/EMBL/DDBJ accession number for the $16 \mathrm{~S}$ rRNA gene sequence of strain $\mathrm{MTO}^{\top}$ is $\mathrm{AY} 894336$.
Strain $\mathrm{MT}^{\mathrm{T}}$ was isolated from sediment collected from the Mariana Trench in the north-west Pacific Ocean [Challenger Deep (10 $\left.898 \mathrm{~m}): 11^{\circ} 19 \cdot 911^{\prime} \mathrm{N} 142^{\circ} 12 \cdot 372^{\prime} \mathrm{E}\right]$ ) using the remotely operated unmanned submersible Kaiko (Kato et al., 1997). The sample (2 ml), which was collected during dive number 74 on 21 May 1998, was transported to the UK in an insulated container at $4{ }^{\circ} \mathrm{C}$ and then stored at $-20^{\circ} \mathrm{C}$. The isolate was recovered from a suspension of the sediment sample used to inoculate a raffinose-histidine agar plate (Vickers et al., 1984) supplemented with cycloheximide and nystatin. The organism was maintained on glucose-yeast extract agar (Gordon \& Mihm, 1962) at room temperature and as glycerol suspensions $(20 \%, \mathrm{v} / \mathrm{v})$ at $-20^{\circ} \mathrm{C}$.

The phylogenetic position of isolate $\mathrm{MT}^{\mathrm{T}}$ was determined by $16 \mathrm{~S}$ rRNA gene sequence analysis. The organism was grown at $28^{\circ} \mathrm{C}$ for 7 days in a glucose-yeast extract shake culture (Gordon \& Mihm, 1962), and the resultant biomass was harvested by centrifugation and washed twice in distilled water. Isolation of chromosomal DNA, PCR amplification and direct sequencing of the purified products of the strain were carried out according to the methods of Kim et al. (2000). The almost complete 16S rRNA gene sequence (1443 nt) was aligned manually with corresponding sequences of representatives of the genera classified in the suborder Corynebacterineae, retrieved from the DDBJ/EMBL/GenBank databases, using the pairwise alignment option and 
$16 \mathrm{~S}$ rRNA secondary structure information held within the PHYDIT program (available at http://plaza.snu.ac.kr/ $\sim$ jchun/phydit/).

Phylogenetic trees were inferred using the least-squares (Fitch \& Margoliash, 1967), maximum-likelihood (Felsenstein, 1981), maximum-parsimony (Kluge \& Farris, 1969) and neighbour-joining (Saitou \& Nei, 1987) tree-making algorithms from the PHYLIP suite of programs (Felsenstein, 1993). Evolutionary distance matrices were generated for the least-squares and neighbour-joining methods after Jukes \& Cantor (1969) and the resultant unrooted tree topologies were evaluated in a bootstrap analysis (Felsenstein, 1985) based on 1000 resamplings from the neighbour-joining dataset using the SEQBOOT and CONSENSE options from the PHYLIP package. It is evident from Fig. 1 that isolate MT8 ${ }^{\mathrm{T}}$ not only falls within the zone of evolutionary radiation occupied by the genus Williamsia but forms a distinct phyletic line together with the type strain of $W$. muralis, an association underpinned by all of the tree-making algorithms and by a $100 \%$ bootstrap value in the neighbourjoining analysis. The two organisms share $99 \cdot 5 \% 16 \mathrm{~S}$ rRNA gene similarity, a value that corresponds to $7 \mathrm{nt}$ differences over the 1450 locations available for alignment.

Isolate $\mathrm{MT}^{\mathrm{T}}$ was the subject of chemotaxonomic analyses designed to determine whether it has chemical properties

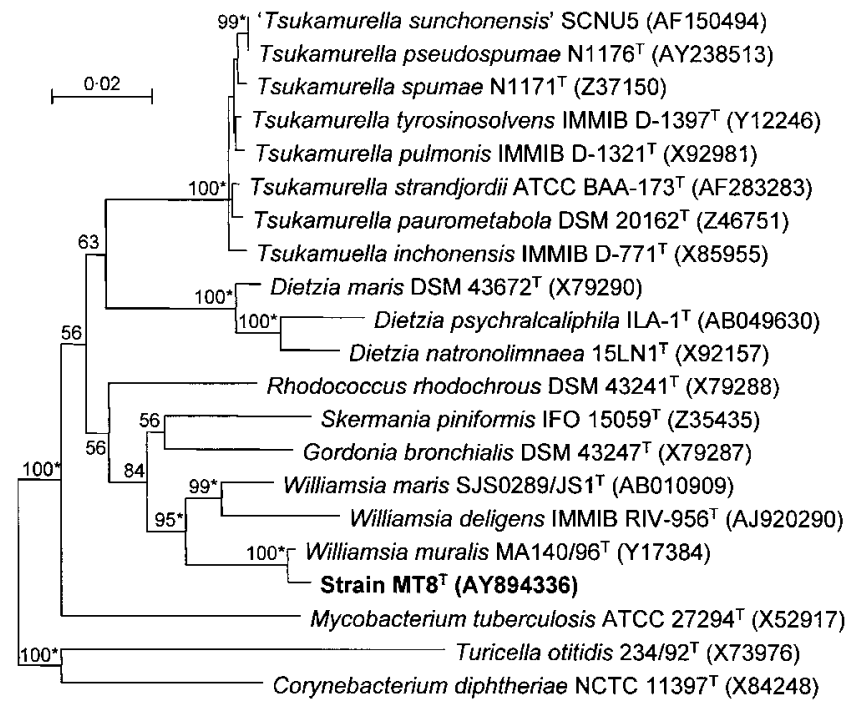

Fig. 1. Neighbour-joining tree (Saitou \& Nei, 1987) based on almost complete $16 \mathrm{~S}$ rRNA gene sequences showing relationships between isolate $M T 8^{\top}$ and representatives of the suborder Corynebacterineae. Asterisks indicate branches that were also recovered using the least-squares (Fitch \& Margoliash, 1967), maximum-likelihood (Felsenstein, 1981) and maximumparsimony (Kluge \& Farris, 1969) treeing-making algorithms. Numbers at nodes indicate levels of bootstrap support based on a neighbour-joining analysis of 1000 resampled datasets; only values above $50 \%$ are given. Bar, 0.02 substitutions per nucleotide position. characteristic of Williamsia strains. The required biomass was prepared from glucose-yeast extract broth cultures (Gordon \& Mihm, 1962) as described above. Standard procedures were used to extract and to analyse the isomeric forms of diaminopimelic acid (Staneck \& Roberts, 1974), fatty acids (Sutcliffe, 2000), mycolic acids (Hamid et al., 1993), isoprenoid quinones (Collins, 1994), muramic acid type (Uchida et al., 1999), polar lipids (Minnikin et al., 1984) and whole-organism sugars (Hasegawa et al., 1983). The organism was characterized by the presence of mesodiaminopimelic acid, arabinose and galactose in wholeorganism hydrolysates (wall chemotype IV sensu Lechevalier \& Lechevalier, 1970), $\mathrm{N}$-glycolyl muramic acid residues, dihydrogenated menaquinones with nine isoprene units as the sole isoprenologue, major proportions of straight-chain, unsaturated and tuberculostearic acids (fatty acid type 1b; Kroppenstedt, 1985), phosphatidylethanolamine, diphosphatidylglycerol, phosphatidylglycerol and phosphatidylinositol as major polar lipids (phospholipid type II sensu Lechevalier et al., 1977) and by mycolic acids that comigrated with those of $W$. muralis DSM $44343^{\mathrm{T}}$. This chemical profile is consistent with the classification of the isolate in the genus Williamsia (Goodfellow \& Maldonado, 2006; Yassin \& Hupfer, 2006).

The fatty acid profile was dominated by palmitic acid $\left(\mathrm{C}_{16: 0}\right.$, $30 \%$ of total), a hexadecenoic acid $\left(\mathrm{C}_{16: 1}, 22 \%\right)$, oleic acid $\left(\mathrm{C}_{18: 1}, 15 \%\right)$ and tuberculostearic acid (10-methyl octadecanoate, $32 \%$ ). This profile is generally consistent with that reported for the type strain of $W$. muralis (Kämpfer et al., 1999), except that the latter organism was reported to contain significant quantities of palmitoleic acid $\left(\mathrm{C}_{16: 1}\right.$ cis 9$)$ whereas we detected a fatty acid provisionally identified as a hexadecenoic acid but clearly resolved from a palmitoleic acid standard. In this respect it is notable that $W$. muralis DSM $44343^{\mathrm{T}}$ was reported to contain a minor amount of $\mathrm{C}_{16: 1}$ cis 11 (1.4\%; Kämpfer et al., 1999). The fatty acid profiles of $\mathrm{MT}^{\mathrm{T}}$ and $W$. muralis DSM $44343^{\mathrm{T}}$ are thus both notably distinct from that reported for the type strain of $W$. deligens as the latter contained only minor amounts of $\mathrm{C}_{16: 1}$ and significant quantities $(40 \%)$ of longer chain $\left(\leqslant \mathrm{C}_{20}\right)$ saturated and unsaturated fatty acids (Yassin \& Hupfer, 2006).

DNA-DNA hybridization experiments were carried out between isolate $\mathrm{MT}^{\mathrm{T}}$ and the type strains of $W$. maris and $W$. muralis using DNA prepared following the methods of Kim et al. (1998). The analyses were performed using the microplate method, as described by Ezaki et al. (1989). Mean DNA-DNA relatedness values were calculated from triplicate hybridization experiments. The $\mathrm{G}+\mathrm{C}$ content of the DNA of isolate $\mathrm{MT}^{\mathrm{T}}{ }^{\mathrm{w}}$ was determined by reversed-phase HPLC (Tamaoka \& Komagata, 1984). The mean levels of DNA-DNA relatedness found between isolate $\mathrm{MT} 8^{\mathrm{T}}$ and W. maris DSM $44693^{\mathrm{T}}$ and W. muralis DSM $44343^{\mathrm{T}}$ were $10 \pm 2 \cdot 8$ and $11 \pm 0 \%$, respectively, values well below the cut-off point recommended for the assignment of bacterial strains to the same genomic species (Wayne et al., 
1987). The DNA G+C content of strain $\mathrm{MT}^{\mathrm{T}}$ was $65 \cdot 2 \mathrm{~mol} \%$.

Isolate $\mathrm{MT}^{\mathrm{T}}$ was examined for a range of phenotypic markers using established procedures (Stach et al., 2004). It is evident from Table 1 that it can be differentiated readily from the type strains of the three recognized Williamsia species. It is particularly interesting that only isolate $\mathrm{MT}^{\mathrm{T}}$ grows at $4{ }^{\circ} \mathrm{C}$ and in the presence of high concentrations of sodium chloride.

It is evident from the genotypic and phenotypic data presented here that isolate $\mathrm{MT}^{\mathrm{T}}$ represents a novel species within the genus Williamsia. The name proposed for this taxon is Williamsia marianensis sp. nov.

\section{Description of Williamsia marianensis sp. nov.}

Williamsia marianensis (ma.ri.an.en'sis. N.L. fem. adj. marianensis pertaining to the Mariana Trench, the source of the type strain).

Non-acid-alcohol-fast actinomycete that forms short rods and coccoid-like elements, and produces round, entire, convex, orange colonies with smooth matt surfaces on glucose-yeast extract agar after 5 days incubation at $28^{\circ} \mathrm{C}$. Grows well on trypticase soy agar, and between 4 and $30^{\circ} \mathrm{C}$, with an optimum temperature for growth around $28^{\circ} \mathrm{C}$.

Table 1. Phenotypic properties that differentiate strain $\mathrm{MT8}^{\mathrm{T}}$ from the type strains of Williamsia species

Reference strains: $1, W$. deligens DSM $44902^{\mathrm{T}}$ (data from Yassin \& Hupfer, 2006); 2, W. maris DSM $44693^{\mathrm{T}}$ (Stach et al., 2004); 3, W. muralis DSM $44343^{\mathrm{T}}$ (Kämpfer et al., 1999).

\begin{tabular}{|c|c|c|c|c|}
\hline Characteristic & $\mathrm{MT8}^{\mathrm{T}}$ & 1 & 2 & 3 \\
\hline \multicolumn{5}{|c|}{$\begin{array}{l}\text { Growth on sole carbon sources at } \\
1 \%(\mathrm{w} / \mathrm{v}) \text { : }\end{array}$} \\
\hline Adonitol & - & - & - & + \\
\hline $\mathrm{L}(+)$-Arabinose & + & - & - & + \\
\hline meso-Erythritol & + & - & - & + \\
\hline $\mathrm{D}(+)$-Galactose & - & - & + & - \\
\hline$m$-Hydroxybenzoate & - & - & - & + \\
\hline p-Hydroxybenzoate & - & - & + & - \\
\hline myo-Inositol & - & - & + & - \\
\hline $\mathrm{D}(+)$-Maltose & - & + & + & - \\
\hline $\mathrm{D}(+)$-Rhamnose & + & - & - & + \\
\hline $\mathrm{D}(+)$-Trehalose & + & + & + & - \\
\hline $\mathrm{D}(+)$-Xylose & - & + & + & - \\
\hline \multicolumn{5}{|l|}{ Growth on: } \\
\hline $5 \%(\mathrm{w} / \mathrm{v}) \mathrm{NaCl}$ & + & - & - & - \\
\hline $7 \%(w / v) \mathrm{NaCl}$ & + & - & - & - \\
\hline $1 \%(\mathrm{v} / \mathrm{v})$ 1,2-Propandiol & - & - & + & - \\
\hline \multicolumn{5}{|l|}{ Growth at: } \\
\hline $4{ }^{\circ} \mathrm{C}$ & + & - & - & - \\
\hline $37^{\circ} \mathrm{C}$ & - & + & + & + \\
\hline
\end{tabular}

Neither aesculin nor arbutin are hydrolysed. Casein, cellulose, hypoxanthine, starch and uric acid are degraded, but not gelatin, guanine, Tween 80 , L-tyrosine or xanthine. $\mathrm{D}(+)$-Fructose, $\mathrm{D}(+)$-mannitol, $\mathrm{D}(+)$-mannose, sucrose, $\mathrm{D}(+)$-sorbitol and xylitol are used as sole carbon sources for energy and growth, but not $\mathrm{L}(-)$-arabitol, $\mathrm{D}(+)$-cellobiose, dextran, dextrin, $\mathrm{D}(+)$-glycerol, glycogen, $\mathrm{D}(+)$-melezitose, $\mathrm{D}(+)$-raffinose, $\mathrm{D}(+)$-salicin or $\mathrm{L}(+)$-sorbose. Additional phenotypic properties are given in Table 1. Exhibits chemical markers characteristic of the genus Williamsia. The predominant fatty acid components are palmitic and tuberculostearic acids. The $\mathrm{G}+\mathrm{C}$ content of the DNA is $65 \cdot 4 \mathrm{~mol} \%$.

The type and only strain, $\mathrm{MT}^{\mathrm{T}}\left(=\mathrm{DSM} 44944^{\mathrm{T}}=\mathrm{NCIMB}\right.$ $14085^{\mathrm{T}}$ ), was isolated from sediment collected from the Challenger Deep of the Mariana Trench in the north-west Pacific Ocean.

\section{Acknowledgements}

W.P.-a. is grateful to the DPST programme and the Royal Thai Government for financial support. We thank the Kaiko operation team and the crew of M.S. Yokosuka for collecting sediment samples and Dr Jean Euzéby for his help in naming the species. The work was supported by the UK Natural Environment Research Council (grants NER/T/S/2000/00614 and NER/T/S/2000/00616). A. T.B. thanks the Leverhulme Trust for the award of an Emeritus Fellowship.

\section{References}

Butler, W. R., Floyd, M. M., Brown, J., Toney, S. R., Daneshvar, M. I., Cooksey, R. C., Carr, J., Steigerwalt, A. G. \& Charles, N. (2005). Novel mycolic acid-containing bacteria in the family Segniliparaceae fam. nov., including the genus Segniliparus gen. nov., with descriptions of Segniliparus rotundus sp. nov. and Segniliparus rugosus sp. nov. Int J Syst Evol Microbiol 55, 1615-1624.

Collins, M. D. (1994). Isoprenoid quinones. In Chemical Methods in Prokaryotic Systematics, pp. 265-309. Edited by M. Goodfellow \& A. G. O’Donnell. Chichester: Wiley.

Ezaki, T., Hashimoto, Y. \& Yabuuchi, E. (1989). Fluorometric deoxyribonucleic acid-deoxyribonucleic acid hybridization in microdilution wells as an alternative to membrane filter hybridization in which radioisotopes are used to determine genetic relatedness among bacterial strains. Int J Syst Bacteriol 39, 224-229.

Felsenstein, J. (1981). Evolutionary trees from DNA sequences: a maximum likelihood approach. J Mol Evol 17, 368-376.

Felsenstein, J. (1985). Confidence limits on phylogenies: an approach using the bootstrap. Evolution 39, 783-791.

Felsenstein, J. (1993). PHYLIP - Phylogeny Inference Package, version 3.5c. Distributed by the author. Department of Genome Sciences, University of Washington, Seattle, USA.

Fitch, W. M. \& Margoliash, E. (1967). Construction of phylogenetic trees: a method based on mutation distances as estimated from cytochrome $c$ sequences is of general applicability. Science 155, 279-284.

Goodfellow, M. \& Maldonado, L. A. (2006). The families Dietziaceae, Gordoniaceae, Nocardiaceae and Tsukamurellaceae. In The Prokaryotes, 3rd edn, vol. 3, Archaea and Bacteria. Firmicutes, Actinomycetes. Edited by M. Dworkin, S. Falkow, E. Rosenberg, K. H. Schleifer \& E. Stackebrandt. New York: Springer (in press). 
Gordon, R. E. \& Mihm, J. M. (1962). Identification of Nocardia caviae (Erikson) nov. comb. Ann N Y Acad Sci 98, 628-636.

Hamid, M. E., Minnikin, D. E., Goodfellow, M. \& Ridell, M. (1993). Thin-layer chromatographic analysis of glycolipids and mycolic acids from Mycobacterium farcinogenes, Mycobacterium senegalense and related taxa. Zentralbl Bakteriol 279, 354-367.

Hasegawa, T., Takizawa, M. \& Tanida, S. (1983). A rapid analysis for chemical grouping of aerobic actinomycetes. J Gen Appl Microbiol 329, 1319-1322.

Jukes, T. H. \& Cantor, C. R. (1969). Evolution of protein molecules. In Mammalian Protein Metabolism, vol. 3, pp. 21-123. Edited by H. N. Munro. New York: Academic Press.

Kämpfer, P., Andersson, M. A., Rainey, F. A., Kroppenstedt, R. M. \& Salkinoja-Salonen, M. (1999). Williamsia muralis gen. nov., sp. nov., isolated from the indoor environment of a children's day care centre. Int J Syst Bacteriol 49, 681-687.

Kato, C., Li, L., Tamaoka, J. \& Horikoshi, K. (1997). Molecular analyses of the sediment of the 11,000-m-deep of the Mariana Trench. Extremophiles 1, 117-123.

Kim, S. B., Falconer, C., Williams, E. \& Goodfellow, M. (1998). Streptomyces thermocarboxydovorans $\mathrm{sp}$. nov. and Streptomyces thermocarboxydus sp. nov., two moderately thermophilic carboxydotrophic species from soil. Int J Syst Bacteriol 48, 59-68.

Kim, S. B., Brown, R., Oldfield, C., Gilbert, S. C., lliarionov, S. \& Goodfellow, M. (2000). Gordonia amicalis sp. nov., a new dibenzothiophene-desulphurizing actinomycete. Int $J$ Syst Evol Microbiol 50, 2031-2036.

Kluge, A. G. \& Farris, F. G. (1969). Quantitative phyletics and the evolution of anurans. Syst Zool 18, 1-32.

Kroppenstedt, R. M. (1985). Fatty acid and menaquinone analysis of actinomycetes and related organisms. In Chemical Methods in Bacterial Systematics, pp. 173-199. Edited by M. Goodfellow \& D. E. Minnikin. London: Academic Press.

Lechevalier, H. A. \& Lechevalier, M. P. (1970). A critical evaluation of the genera of aerobic actinomycetes. In The Actinomycetales, pp. 393-405. Edited by H. Prauser. Jena: VEB Gustav Fischer.

Lechevalier, H. A., De Bièvre, C. \& Lechevalier, M. P. (1977). Chemotaxonomy of aerobic actinomycetes: phospholipid composition. Biochem Syst Ecol 5, 249-260.

Minnikin, D. E., O'Donnell, A. G., Goodfellow, M., Alderson, G., Athalye, M., Schaal, A. \& Parlett, J. H. (1984). An integrated procedure for the extraction of isoprenoid quinones and polar lipids. J Microbiol Methods 2, 233-241.

Pathom-aree, W., Stach, J. E. M., Ward, A. C., Horikoshi, K., Bull, A. T. \& Goodfellow, M. (2006). Diversity of actinomycetes isolated from the Challenger Deep sediment $(10898 \mathrm{~m})$ from the Mariana Trench. Extremophiles (in press).

Saitou, N. \& Nei, M. (1987). The neighbor-joining method: a new method for reconstructing phylogenetic trees. Mol Biol Evol 4, 406-425.

Soddell, J. A., Stainsby, F. M., Eales, K. L., Kroppenstedt, R. M., Seviour, R. J. \& Goodfellow, M. (2006). Millisia brevis gen. nov., sp. nov., an actinomycete isolated from activated sludge foam. Int J Syst Evol Microbiol 56, 739-744.

Stach, J. E. M., Maldonado, L. A., Ward, A. C., Bull, A. T. \& Goodfellow, M. (2004). Williamsia maris sp. nov., a novel actinomycete isolated from the Sea of Japan. Int J Syst Evol Microbiol 54, 191-194.

Stackebrandt, E., Rainey, F. A. \& Ward-Rainey, N. L. (1997). Proposal of a new hierarchic classification system, Actinobacteria classis nov. Int J Syst Bacteriol 47, 479-491.

Staneck, J. L. \& Roberts, G. D. (1974). Simplified approach to the identification of aerobic actinomycetes by thin layer chromatography. Appl Microbiol 28, 226-231.

Sutcliffe, I. C. (2000). Characterisation of a lipomannan lipoglycan from the mycolic acid containing actinomycete Dietzia maris. Antonie van Leeuwenhoek 78, 195-201.

Tamaoka, J. \& Komagata, K. (1984). Determination of DNA base composition by reverse-phase high-performance liquid chromatography. FEMS Microbiol Lett 25, 125-128.

Uchida, K., Kudo, T., Suzuki, K. \& Nakase, T. (1999). A new rapid method of glycolate test by diethyl ether extraction, which is applicable to a small amount of bacterial cells of less than one milligram. J Gen Appl Microbiol 45, 49-56.

Vickers, J. C., Williams, S. T. \& Ross, G. W. (1984). A taxonomic approach to selective isolation of streptomycetes from soil. In Biological, Biochemical and Biomedical Aspects of Actinomycetes, pp. 553-561. Edited by L. Ortiz-Ortiz, L. F. Bojalil \& V. Yakoleff. Orlando: Academic Press.

Wayne, L. G., Brenner, D. J., Colwell, R. R. \& 9 other authors (1987). Report of the ad hoc committee on reconciliation of approaches to bacterial systematics. Int J Syst Bacteriol 37, 463-464.

Yassin, A. F. \& Hupfer, H. (2006). Williamsia deligens sp. nov., isolated from human blood. Int J Syst Evol Microbiol 56, 193-197. 